\title{
Efforts to Improve Management of Student Health Services at Islamic Boarding Schools in Indonesia
}

\author{
Emy Rianti $^{1 *}$, Agus Triwinarto ${ }^{2}$ \\ ${ }^{1}$ Health Polytechnic of Jakarta I, Indonesia \\ ${ }^{2}$ Center for Research and Development of Public Health Efforts, Indonesia \\ *Corresponding Author. Email: emyrianti@gmail.com
}

\begin{abstract}
Islamic boarding school (Pesantren) is Islamic educational and broadcasting institution, which contain the history and authenticity in Indonesia. The number of pesantren in Indonesia continues to grow from year to year, and one of the life problem faced by the students (Santri) is the problem of cleanliness due to the lack of clean water availability and management in pesantren. This study aims to determine the factors that influence personal hygiene practices between students in Islamic boarding schools located in urban and rural areas. The results of this study proves that the management of health services in Islamic boarding schools affects the personal hygiene behavior of Santri, especially in Islamic boarding schools who is located in rural areas which still use water pond (Kulah) as one of water source to fulfil their daily needs.
\end{abstract}

Keywords: management, pesantren, Poskestren

\section{INTRODUCTION}

Islamic boarding schools in Indonesia have a very large role, both for the advancement of Islamic education itself and for the Indonesian people as a whole. In general, there are quite a lot of health problems in Islamic boarding schools, including those related to environmental health such as scattered rubbish, dirty floors, non-flowing waste water, rarely drained bathtubs, and behavior-related problems.

In 2015-2016, the level of education in Primary school (Madrasah ibtidaiyah/ MI) was $86.70 \%$, Junior high school (Madrasah tsanawiyah/ MTs) was $76.37 \%$ and Senior high school (Madrasah aliyah/ MA) was $67.94 \%$. The average level of people whom are educated Muslims throughout Indonesia is $67.25 \%$ (EMIS, 2016). There are 28,194 pesantren which are spread both in urban and rural areas with 4,290,626 santri, and all of them are private. This illustrates that community participation in Islamic education (Madrasah) is very large, for this reason it is fitting to be a measure of government attention.

The joint decision of the Minister of Health of the Republic of Indonesia, the Minister of Religion of the Republic of Indonesia and the Minister of Home Affairs of the Republic of Indonesia in 2002 concerning health improvement in Islamic boarding schools and other religious institutions. Regulation of the Minister of Health of the Republic of Indonesia in 2013 concerning guidelines for organizing and developing boarding school health posts.

\begin{abstract}
Healthy boarding school is one of the Ministry of Health programs which is one of the priorities in 2019. In pesantren, santri and Kyai or Teachers play an important role in realizing healthy boarding schools, as well as the boarding schools community, the capacity of potential partners, and healthoriented policies. Healthy boarding schools aim to increase knowledge and awareness of the importance of health. It is related to the age of the students and also national priority health issues such as the healthy living community movement, elimination, tuberculosis, preventing stunting, and increasing immunization coverage among boarding school communities (Indonesian Health Ministry, 2019).
\end{abstract}

\section{METHOD}

This research is using Cross Sectional method with quantitative and qualitative approaches. The number of samples were 97 students, which were determined using a different proportion hypothesis formula. The technique in determining the location of sample units used the purposive sampling judgment, whilst the technique of determining individual samples by random sampling. Inclusion criteria, students in first grade of secondary schools $(M T s)$, whom are in boarding schools for at least 5 months. Data were collected through questionnaires and interviews with students and managers of Islamic boarding schools, as well as field observations. The location of study was conducted in two Islamic boarding schools, named: Al-Hamidiyah Islamic Boarding School (urban), located on Sawangan 
Depok street, and at the Qothrotul Falah Islamic Boarding School (rural), which is located on Sampay-Cileles street, Banten Province.

\section{RESULTS AND DISCUSSION}

Table 1. Characteristics of Boarding Schools

\begin{tabular}{lll}
\hline $\begin{array}{l}\text { Characteristi } \\
\text { cs }\end{array}$ & Al Hamidiyah & \multicolumn{1}{c}{ Qothrotul Falah } \\
\hline $\begin{array}{l}\text { Location } \\
\text { Criteria }\end{array}$ & $\begin{array}{l}\text { Urban } \\
\text { Combination } \\
\text { (Traditional }\end{array}$ & Rural \\
& $\begin{array}{l}\text { Combination (Traditional } \\
\text { Modern }\end{array}$ & Modern) Pesantren \\
Pesantren & \\
Water & Artesian Well & Artesian Well and Water Pond \\
Sources & No & No \\
$\begin{array}{l}\text { Poskestren } \\
\text { Treatment } \\
\text { Clinic }\end{array}$ & Yes & No \\
\hline
\end{tabular}

Table 2. Gender Relationship, Knowledge, Attitudes, and health services with behavior

\begin{tabular}{|c|c|c|c|c|c|c|c|c|}
\hline \multirow{3}{*}{$\begin{array}{c}\text { Pesantr } \\
\text { en }\end{array}$} & \multirow{3}{*}{$\begin{array}{l}\text { Varia } \\
\text { ble }\end{array}$} & \multicolumn{4}{|c|}{ Behavior } & \multirow{3}{*}{$\begin{array}{c}P \\
\text { valu } \\
e\end{array}$} & \multirow{3}{*}{ OR } & \multirow{3}{*}{$95 \%$ CI } \\
\hline & & \multicolumn{2}{|c|}{ Good } & \multicolumn{2}{|c|}{ Less } & & & \\
\hline & & n & $\%$ & $n$ & $\%$ & & & \\
\hline \multicolumn{9}{|l|}{$\begin{array}{l}\text { Al } \\
\text { Hamidi } \\
\text { yah } \\
\end{array}$} \\
\hline \multirow[t]{2}{*}{ Gender } & $\begin{array}{l}\text { Wom } \\
\text { en }\end{array}$ & 17 & $\begin{array}{c}73.9 \\
0\end{array}$ & 6 & $\begin{array}{c}26.1 \\
0\end{array}$ & 0.29 & $\begin{array}{c}0.3 \\
9\end{array}$ & $0.09-1.58$ \\
\hline & Man & 29 & $\begin{array}{c}87.9 \\
0\end{array}$ & 4 & $\begin{array}{c}12.1 \\
0\end{array}$ & & & \\
\hline \multirow{2}{*}{$\begin{array}{l}\text { Knowle } \\
\text { dge }\end{array}$} & Good & 34 & $\begin{array}{c}82.9 \\
0\end{array}$ & 7 & $\begin{array}{c}17.1 \\
0\end{array}$ & 1.01 & $\begin{array}{c}1.2 \\
1\end{array}$ & $0.27-5.46$ \\
\hline & Less & 12 & $\begin{array}{c}80.0 \\
0\end{array}$ & 3 & $\begin{array}{c}20.0 \\
0\end{array}$ & & & \\
\hline \multirow[t]{3}{*}{ Attitude } & Good & 29 & $\begin{array}{c}85.3 \\
0\end{array}$ & 5 & $\begin{array}{c}14.7 \\
0\end{array}$ & 0.49 & $\begin{array}{c}1.7 \\
0\end{array}$ & $0.43-6.75$ \\
\hline & Less & 17 & $\begin{array}{c}77.3 \\
0\end{array}$ & 5 & $\begin{array}{c}22.7 \\
0\end{array}$ & & & \\
\hline & Yes & 18 & $\begin{array}{c}78.3 \\
0\end{array}$ & 5 & $\begin{array}{c}21.7 \\
0\end{array}$ & & & \\
\hline \multirow[t]{2}{*}{$\begin{array}{l}\text { Health } \\
\text { Service } \\
s\end{array}$} & Yes & 30 & $\begin{array}{c}93.8 \\
0\end{array}$ & 2 & 6.30 & 0.01 & $\begin{array}{c}7.5 \\
0\end{array}$ & $\begin{array}{l}1.42- \\
39.61\end{array}$ \\
\hline & No & 16 & $\begin{array}{c}66.7 \\
0\end{array}$ & 8 & $\begin{array}{c}33.3 \\
0\end{array}$ & & & \\
\hline \multicolumn{9}{|c|}{$\begin{array}{l}\text { Qothrotul } \\
\text { Falah }\end{array}$} \\
\hline \multirow[t]{2}{*}{ Gender } & $\begin{array}{l}\text { Wom } \\
\text { en }\end{array}$ & 18 & $\begin{array}{c}81.1 \\
0\end{array}$ & 4 & $\begin{array}{c}18.2 \\
0\end{array}$ & 0.01 & $\begin{array}{c}9.7 \\
5\end{array}$ & $\begin{array}{l}2.28- \\
41.66\end{array}$ \\
\hline & Man & 6 & $\begin{array}{c}31.6 \\
0\end{array}$ & 13 & $\begin{array}{c}68.4 \\
0\end{array}$ & & & \\
\hline \multirow[t]{2}{*}{$\begin{array}{l}\text { Knowle } \\
\text { dge }\end{array}$} & Good & 16 & $\begin{array}{c}64.0 \\
0\end{array}$ & 9 & $\begin{array}{c}36.0 \\
0\end{array}$ & 0.37 & $\frac{1.7}{7}$ & $0.49-6.36$ \\
\hline & Less & 8 & $\begin{array}{c}50.0 \\
0\end{array}$ & 8 & $\begin{array}{c}50.0 \\
0\end{array}$ & & & \\
\hline \multirow[t]{2}{*}{ Attitude } & Good & 18 & $\begin{array}{c}64.3 \\
0\end{array}$ & 10 & $\begin{array}{c}35.7 \\
0\end{array}$ & 0.27 & $\begin{array}{l}2.1 \\
0\end{array}$ & $0.55-7.99$ \\
\hline & Less & 6 & $\begin{array}{c}46.2 \\
0\end{array}$ & 7 & $\begin{array}{c}53.8 \\
0\end{array}$ & & & \\
\hline \multirow{2}{*}{$\begin{array}{l}\text { Health } \\
\text { Service } \\
s\end{array}$} & Yes & 19 & $\begin{array}{c}86.4 \\
0\end{array}$ & 3 & $\begin{array}{c}13.6 \\
0\end{array}$ & 0.01 & $\begin{array}{l}17 . \\
73\end{array}$ & $\begin{array}{l}3.62- \\
86.89\end{array}$ \\
\hline & No & 5 & $\begin{array}{c}26.3 \\
0\end{array}$ & 14 & $\begin{array}{c}73.7 \\
0\end{array}$ & & & \\
\hline
\end{tabular}

Table 1 shows that there is stiff water as a source of water in Islamic boarding schools located in rural areas as a source of water used daily besides wells / pumps. The results of interviews and observations at the Qothrotul Falah Islamic Boarding School showed that the Islamic boarding school provided many water taps for ablution, bathing and washing for the students, so that clean water facilities were considered to be sufficient. Additional water source is in the form of a stove with a size of $\pm 20 \times 4 \mathrm{~m} 2$, which is made of soil which is used to collect rain water and is used for washing, bathing and performing ablution. Kulah is used together by male students. Kulah will hold a lot of water during the rainy season and dry out during the dry season.
The water is brown because it is mixed with clay. The pesantren considers that the sanctity of water in kulah is unquestionable as long as the water exceeds two kulah. Two kulah in the present size are about 270 liters. The amount of water when splashed with water used for ablution, the water will remain holy and purify. As long as the water does not change its original character (color, smell and taste) due to being unclean, it can still be used for ablution again. But if the water in a container of less than 270 liters is used for ablution or bathing, then the entry of water that has been used for ablution, then the water is considered to have been used. The water is physically sacred, but cannot be used for purification, although it can still be used for other purposes such as regular hand washing.

Dirty is not necessarily impure but certainly not healthy. In the context of sacred bodies and places, not inner sanctum, sacred means that there is no impure, either mild impure, impure, or heavy impure. Whereas clean means the absence of impurities which disturbs the health of the santri. Dirt can be in the form of garbage, animal waste, slums and the like. The exercise of any kind of worship, without physical and mental cleansing, will not be accepted. Therefore, the acceptance of worship also depends on cleanliness. If worship is a tangible manifestation of the exercise of faith, then the ingredients are also part of the faith itself.

The results of an interview with an urban boarding school about a Poskestren, that if there are sick people, they are immediately taken to the pesantren's clinic which has a doctor on duty. Meanwhile, based on the results of interviews with rural pesantren, if someone is sick, they are taken to the puskesmas for treatment. There were no Poskestren in both pesantren, both pesantren said that there was no coaching and collaboration with the Puskesmas.

Table 2 shows the differences in the relationship between the factors that influence the gender of the respondents with personal hygiene behavior, more male respondents who behaved well in the Al Hamidiyah boarding school, and female respondents who behaved more or less in the $\mathrm{Al}$ Hamidiyah boarding school.

Distribution of the relationship between knowledge and behavior, more respondents who have good knowledge and good behavior in Al Hamidiyah Islamic boarding school compared to Qothrotul Falah boarding school. Distribution of the relationship between attitude and behavior, more respondents who have good attitudes and good behavior in Al Hamidiyah Islamic boarding school compared to Qothrotul Falah boarding school, while respondents who have less attitude and good behavior in Al Hamidiyah boarding school. 
[12] Kementerian Kesehatan RI, Peraturan Menteri

\section{CONCLUSION}

This study proves that personal hygiene behavior of santri in Islamic boarding schools in both urban and rural areas is related to boarding school health services and boarding school management.

For academics: Need further research on the pattern of the use of water pond, so that water pond can be a source of holy and clean water according to the teachings of Islam that is perfect. For policy makers: Formulate guidelines for managing clean water supply for Islamic boarding schools and review the guidelines for organizing and fostering boarding school health posts

\section{REFERENCES}

[1] Abdel-Hady El-Gilany, Karima Badawi, Sanaa ElFedawy. Menstrual Hygiene among Adolescent Schoolgirls in Mansoura Egypt. Reproductive Health Matters 13. 2005

[3] Baur, J. Sarkar, N. Manna, L. Bandyopadhyay. The Pattern of Dermatological Disorders among Patients Attending the Skin O.P.D of A Tertiary Care Hospital in Kolkata, India. Journal of Dental and Medical Sciences 3. 2013.

[4] Biro Komunikasi dan Pelayanan Masyarakat, Kementerian Kesehatan RI. 2019.http://www.depkes.go.id/article/view/190109000 02/tingkatkan-kesehatan-santri-kemenkes-bina-pesantrensehat.html

[5] Education Management Information System. 2015/2016. http://pendis.kemenag.go.id/index.php?a=detil \&id=9405

[6] Elizabeth Mc Donald, David Brewster, Ross Bailie, Jocelyn Grace. An Ecological Approach to Health Promotion in Remote Australian Aboriginal Communities. Health Promotion International 25. 2010.

[7] Gilbert, Glen G., Sawyer, Robin G., McNeill, Elisa Beth. Health Education, Creating Strategies for School and Community Health. 3 ed. Sudbury, Massachusetts: Jones and Bartlett Publishers, 2010

[8] Hasil wawancara dengan pengurus Pondok Pesantren Al Hamidiyah. Kota Depok; 2014.

[9] Hasil wawancara dengan pengurus Pondok Pesantren Qothrotul Falah. Banten; November, 2014.

[10] Kementerian Pendidikan dan Kebudayaan RI, Undang Undang No. 20 Tahun 2003. Tentang: Sistem Pendidikan Nasional. Jakarta: 2003.

[11] Kementerian Kesehatan RI, Undang Undang No. 23 Tahun 1992. Tentang: Kesehatan. Jakarta, 1992.
Kesehatan RI Nomor 1 Tahun 2013 Tentang: Pedoman Penyelenggaraan Dan Pembinaan Pos Kesehatan Pesantren. Jakarta: 2013.

[13] Lwanga K. Stephen and Lemeshow Stanley. Sample size determination in health studies, a practical manual. Geneva: World Health Organization, 2014.

[14] N. Raza, R.N.S. Qadir, H. Agna. Risk faktor for scabies among male soldier in Pakistan: case-control study. Eastern Mediterranean Health Journal 15 .2009.

[15] RI, Kementerian Agama.Analisis Statistik Pendidikan Islam Tahun 2015/2016. http://pendis.kemenag.go.id/. Pdf.

[16] Trihono, Gitawati Retno, Hubungan Antara Penyakit Menular dengan Kemiskinan di Indonesia.(Pusat Penelitian dan Pengembangan Biomedis dan Farmasi, Balitbangkes). Jurnal Penyakit Menular Indonesia 1. 2009.

[17] RI, Kementerian Pendidikan dan Kebudayaan. Undang Undang No. 20 Tahun 2003, Tentang: Sistem Pendidikan Nasional. Jakarta ; 2003.

[18] RI, Kementerian Kesehatan RI. Undang Undang No. 23 Tahun 1992. Tentang: Kesehatan. Jakarta; 1992.

[19] RI, Kementerian Kesehatan. Keputusan Bersama Menteri Kesehatan Republik Indonesia, Menteri Agama Republik Indonesia Dan Menteri Dalam Negeri Republik Indonesia Nomor 1067/Menkes/Skb/Viii/2002, Nomor 385 Tahun 2002, Nomor 37 Tahun 2002, Tentang: Peningkatan Kesehatan Pada Pondok Pesantren Dan Institusi Keagamaan Lainnya. Jakarta ; 2002.

[20] RI, Kementerian Kesehatan RI. Peraturan Menteri Kesehatan RI Nomor 1 Tahun 2013 Tentang: Pedoman Penyelenggaraan dan Pembinaan Pos Kesehatan Pesantren. Jakarta; 2013.

[21] Rianti, Emy. Personal Higiene dalam Perpektif Islam. Jakarta ; Maret, 2017

[22] Undang-undang Dasar Negara RI Tahun 1945, pasal 31 ayat 1 . Jakarta, 1945. 